Copyright (C) 2015 by Academic Publishing House Researcher

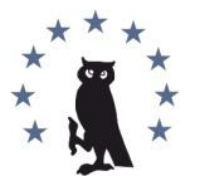

Published in the Russian Federation

European Researcher

Has been issued since 2010.

ISSN 2219-8229

E-ISSN 2224-0136

Vol. 98, Is. 9, pp. 667-683, 2015

DOI: 10.13187/er.2015.99.667

www.erjournal.ru

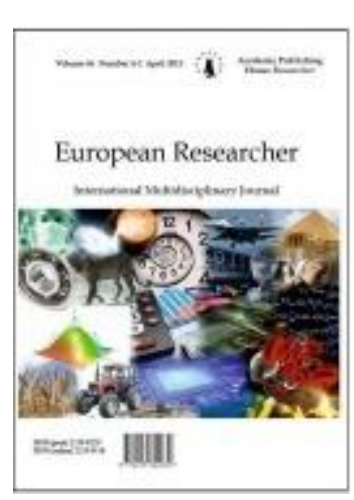

UDC 33

\title{
An Analyses and Solution Proposals Toward Social Gender Equality Problems in Business Life at Work Place in Turkey
}

\author{
${ }^{1}$ Ayse Kocabacak \\ ${ }^{2}$ Cumali Kalkan
}

\author{
${ }^{1}$ Basari University, Faculty of Management, Samsun, Turkey \\ Asst. Prof. Dr. \\ ${ }^{2}$ Mevlana University, Konya, Turkey \\ M.Sc.
}

\begin{abstract}
Gender inequality is a problem in the World as well as in Turkey. What is referred by this problem here is the gender discrimination and thus inequality and injustice in opportunities that women face in a society. It appears in different forms in business life or at work place (inequalities in employment, wages, social benefits and education as well as obstacles in career rise, easy dismissal or layoff, sexual harassment / persecution / mobbing, etc.). In this study, this problem is investigated and evaluated in terms of gender equality issues that women face in Turkey especially in business life. For this purpose, current situation analysis and findings in Turkey from past to present have been made, statistical comparisons have been given against global averages, in which areas of business life it appears the most and from what reasons it originates, reason for its persistence and improvement over time has been researched, and based on our findings, recommendations for possible solutions have been presented.

Keywords: gender equality, gender inequality, gender discrimination, Turkey.

\section{Introduction}

In the world, there is a general understanding (acknowledgement) for gender equality that men and women should receive equal treatment in society, and should not be discriminated based on gender, unless there is a sound biological reason behind. This is also the objective of the United Nations Universal Declaration of Human Rights, which seeks to create equality in law and in social situations, such as in democratic activities and at work.

Gender inequality seems to be bad for economic growth, so it may cause and perpetuate poverty and vulnerability in a society as a whole.

Where gender inequality exists, it is generally women who are excluded or disadvantaged in relation to decision-making and access to economic and social resources.

According to the current data, although Turkey has made some significant structural reforms, democratic expansions, improvements in education and economic development over recent years and has shown some significant efforts and progress toward reducing the gender gap in its economic, political and social life, Turkey has still fallen short of realizing the goal of gender
\end{abstract}


equality by most standards, meaning that the current progress in this problem in Turkey is still not at the desired level.

In business life, especially in the private sector (automotive, construction, etc.) and in some certain professional fields (such as engineering), and again especially at senior management and/or decision-making positions, employment rates of women in terms of qualification and quantity are still found to be low. Women are engaged more in labor-intensive, low-wage and unskilled jobs and works that do not require expertise such as in agriculture as well as in certain sectors like service and in the secondary labor markets. On a broader basis, women are more in positions where they are directed by a superior rather than being manager or director and are unable to find adequate opportunities in the primary labor markets.

The gender equality issue is generally and mainly based on sociological, cultural, educational, economical, structural-constitutional, political, ideological, organizational-institutional, personal, physiological / biological, psychological and sexual reasons. Some of these reasons are associated with societal features of the society (social structure, family structure, culture, religion, customstraditions, common practice/usage, genetic, race, etc.). To these, some other factors like world market situation and political conjuncture within certain time period, global competition, geographical location, climate, working conditions, unionization - organization and extensity of social solidarity networks (e.g. old boys) may also be added. As a result, women are exposed to adverse effects and thus injustices in business life, such as formation of glass ceiling.

These causes have effect on the problem at varying degrees. Therefore, eliminating some of the causes in a place may alleviate the problem partially. However, as the other factors continue to exist, the problem also continues to persist to an extent based on the effect of the continuing factors on the problem. Therefore, improvements in alleviation of the problem vary depending on the society and the degree at which that particular cause affect the problem in that society.

It is evident that the problem is multi-dimensional and arises from many factors that are interrelated/interactive or independent from each other. In this regard, the solution must also be dealt comprehensively and from many aspects or needs to include achievements or progress in many areas.

Some of these solutions may require social reconstructionism or deep and big scaled structural and legal changes that may call for conciliation or general consensus in a society. Some economical applications or solutions possess a financial dimension and call for creating additional financial resources or budget allocation. And solutions of some causes (social, sociological, cultural, etc.) cannot be expected to show dramatic improvement in the short term and may have to be spread over time.

Despite all of these, some short-and medium-term measures can be taken that do not require huge financial liabilities to achieve development in some areas using available resources and facilities and in accordance with strategic targets. Such measures may be listed as training and raising awareness and consciousness at all levels, positive discrimination in favor of women, facilitating and creating more flexible and easier working conditions for women by using modern communication and technological tools, emphasizing the importance of emotional intelligence that may be more prominent in woman and is also important in managing business today, encouraging woman organizations, promoting the dissemination of women social networking, etc.). These solutions have been proposed and have been examined in more detail in the rest of the article.

Moreover, long-term plans and policies should also be developed for controlled and continuous improvement of the problem and for striving to reach universal values. Proposals to these issues have also been discussed in the conclusion section of the article.

\section{Literature review for Turkey}

Social gender is different from biological gender. Social gender varies from one society to another and from one culture to another; nevertheless it is based on the structure of a society and culture. In this regard, social gender, not only specifies the gender differences but also includes the issue of gender discrimination and unequal power interrelations between the two genders (TÜBAKKO, 2012: 53).

It is possible to examine the gender related problems faced by women in business life in five major groups (www.tisk.org.tr):

I. inequality in education and vocational training 
II. inequality in recruitment and raising career

III. inequality in payment

IV. inequality in benefiting from social rights

V. sexual harassment

Labor market participation of women across the globe and working conditions are different than men. The universal features that reflect secondary position of women in the labor market and adverse working conditions are as follows (Özçatal, 2009:45):

- They encounter discriminatory practices during recruitment, promotion, layoff and payment in the labor market,

- $\quad$ They are concentrated in the lower ranks of the hierarchy in the workplace, take up less space in the decision-making and management-related upper positions

- $\quad$ They work in jobs that are monotonous and repetitive and require lower qualification in the production of goods and services

- $\quad$ They lack social protection, are easily abandoned and their labor union organization is weak

- $\quad$ They are concentrated in certain sectors, industries and occupations. In the industrial sector they concentrate in labor-intensive jobs with low paid wages, in fields that require unskilled workers and affected by the economic crisis faster and adversely

Despite some positive developments in recent years pertaining to women education and their employment, this development is not at desired level. The number of women working at certain professions (especially management) is still low and women prefer to work in traditional occupations that offer low income, have limited career rise or promotion opportunity and can interface with homemaking. (Kuzgun ve Sevim, 2004:15).

\section{Obstacles and Reasons for Gender Discrimination Faced by Women In Business Life in Turkey}

Obstacles faced by working women in business life may be associated with causes such as social, organizational and individual (woman's self). It can be said that there are similar reasons on the basis of the obstacles faced by unskilled, semi-skilled and skilled female employees. In this study, these obstacles and reasons are presented and supported by various research findings from the literature.

\subsection{Social Reasons}

One of the important factors that women's participation in Turkish society in working life has not reached the desired level is that the society is still not able to overcome the traditional pressures despite all reforms. Traditional view of the manner towards women in the workforce still persists in large segments of the society. The primary role that the society and the woman gives herself is "wife and mother" and naturally "housewife. As long as this continues, defining the female labor force as "cheap labor", "helping family worker" and in similar forms is unavoidable (Kuzgun ve Sevim, 2004:15).

For women to be successful in business life depend on social values and culture to a great extent. Women are expected to meet the needs of their husbands, children and parents. When women participate to working life, they are not only expected to fulfill the work requirements, but also the duties imposed by society (family and child care, house maintenance etc.).

An individual's identity is shaped under the influence of his family first, then his educational institutions and occupational and socializing place. During this process, social gender identity of the individual is acquired, during which boys and girls identify themselves with character and individuality related to their own gender. There are norms in the society for "masculine and feminine" identity. Males are expected to acquire the masculine and females are expected to acquire the feminine identity in a society. (Güldal, 2006:64).

Whereas feminine characteristics comprise of "democratic, addiction, sensuality, risk aversion, empathy, abstention, collaborative, passivity, refusing to pursue, soft, adapt, acceptance, helplessness, passive, protective and home bound"; masculine characteristics comprise of "autocratic, independence, rationality, risk taking, being dominant, assertive, individualistic, 
active, pursue success, competitive, tough, possessive, judgmental, pro-active, not protective, street biased" qualities (Güldal, 2006:64-65).

What boys and girls are learning in the process of socialization, what the culture imposes on their gender for 'proper' feelings, attitudes, behaviors and differences between the roles can be considered as social gender differences. Women are perceived as more sensitive, relevant and caregiver, etc. They are expected to be homemaker, teacher, nurse, etc. On the other hand, men are perceived as independent, aggressive, strong, etc. and expected to be soldiers, engineers, traders and so on. These are the social gender differences. They are not real differences that happen as a result of society's impose its own patterns on the individual (Balkır, 2012:1).

\subsection{Organizational Reasons}

Elements that create glass ceiling effect in organizations may be collected around individual, organizational and social factors as follows (glass ceiling obstacles):

Barriers arising from Individual Factors

- $\quad$ Multi-Role Playing

- Women's personal preferences and perceptions

Barriers arising from Organizational Factors

- Organizational Culture

- $\quad$ Organization Policies

- Lack of Mentor

- Inability to participate in Informal Networks

Barriers arising from Social Factors

- $\quad$ Career Distinction

- $\quad$ Stereotypes (Rigid Prejudices associated to gender)

All leaders are comprised of almost men, and this means that men are decisive in the formation of organizational culture. Therefore, the organization culture is reported to be attributed to having such characteristics as aggressiveness, competitiveness, success orientation and independence that refer to men (Güldal, 2006:68).

Business life is founded and is governed largely by men. Because business life is shaped by the traditional gender roles of man, women's participation in work and social life requires a more difficult process to take place (Dolmacı ve Türeli, 2012:2).

In male-dominated organizational culture, women are excluded from men's informal channels of communication, so women are singled in the organization. For women it is very difficult to enter into the network of the "old boys". This is a major barrier for woman to progress in her career (Mercanlıŏlu, 2009:41).

Many studies examining the relationship between gender and mobbing show that female employees are more exposed to mobbing than male employees. There are research concluding that women are often managed and male are managers in business life triggers mobbing behavior and therefore create gender discrimination (Aksakal, 2009:116).

\subsection{Individual Reasons (arising from woman herself)}

Among the most significant barriers for women to become senior managers is "lack of confidence, lack of ambition formed by the prejudice that she will fail somehow, not preferring promotion as not to be ready to pay the price, internalizing without questioning the roles the society expects from them". These are the individual barriers created by woman herself. According to researches done with married women, we see that when they left the job to bear a child, they are unable to continue where they left upon return, they are stumbling at their career ladder and are willing to work for less salary (Mercanlığlu, 2009:42-43).

Some of the problems women face is sourced by intense pace of work and stress that the feeling create about 'neglecting' their homes and children. Married women with career are expected to be "super women" who can both handle housework and accomplish working full time (Demiriz ve Yaşar, 2009:86). 


\subsection{Combined Reasons}

Cinar (1994) gives below sociological reasons as to why unskilled women are not working in the primary jobs:

i. The importance of flexible working hours for mothers with small children,

ii. The problems encountered regarding permission by husband,

iii. Not to lose credibility in the eyes of neighbors and relatives, workers,

iv. Difficulties encountered in job promotion and salary increases as compared with male

v. Potential harassment incidents that they may face in the workplace (Dedeoğlu, 2000: 164).

\section{Turkey's Current Situation Compared to World}

United Nations Development Program has developed an index called Global Gender Gap Index (GDI) regarding the elimination of gender inequality and also Gender Empowerment Measure (GEM) measuring the participation and distribution of women in economic and political life. On the other hand, there is a Global Gender Inequality Report prepared by World Economy Forum which is another important data source using 14 various parameters (Dolmacı ve Türeli, 2012:5).

Turkey is in the 68. rank (2012) in terms of United Nations Social Gender Inequality Index (GII), in 120. rank among 136 countries in Global Gender Gap Report (2013) of World Economy Forum (TEPAV, 2014). years.

The following tables give an idea about Turkey's situation as compared to other countries by

United Nations Development Program (UNDP) Table 4: Gender Inequality Index (2012):

\begin{tabular}{|c|c|c|c|c|c|c|}
\hline $\begin{array}{c}\text { Gender } \\
\text { Inequality } \\
\text { Index } \\
\text { Rank }\end{array}$ & $\begin{array}{c}\text { Gender } \\
\text { Inequality } \\
\text { Index } \\
\text { Value }\end{array}$ & $\begin{array}{c}\text { 2012 Seats } \\
\text { in National } \\
\text { Parliament } \\
\text { (\% female) }\end{array}$ & $\begin{array}{c}\text { 2006-2010 } \\
\text { Population } \\
\text { with at least } \\
\text { secondary } \\
\text { education } \\
\text { (Female) }\end{array}$ & $\begin{array}{c}\text { 2006-2010 } \\
\text { Population } \\
\text { with at least } \\
\text { secondary } \\
\text { education } \\
\text { (Male) }\end{array}$ & $\begin{array}{c}\text { 2011 Labour } \\
\text { force } \\
\text { participation } \\
\text { rate (Female) }\end{array}$ & $\begin{array}{c}\text { 2011 Labour } \\
\text { force } \\
\text { participation } \\
\text { rate (Male) }\end{array}$ \\
\hline 68 & 0,366 & 14,2 & 26,7 & 42,4 & 28,1 & 71,4 \\
\hline
\end{tabular}

The Global Gender Gap Index 2013 rankings:

\begin{tabular}{|l|c|c|c|c|c|c|c|c|c|}
\hline Country & $\begin{array}{c}2013 \\
\text { rank }\end{array}$ & $\begin{array}{c}2013 \\
\text { score }\end{array}$ & $\begin{array}{c}2013 \text { rank } \\
\text { among } 2012 \\
\text { countries }\end{array}$ & $\begin{array}{c}2012 \\
\text { rank }\end{array}$ & $\begin{array}{c}2012 \\
\text { score }\end{array}$ & $\begin{array}{c}2011 \\
\text { rank }\end{array}$ & $\begin{array}{c}2011 \\
\text { score }\end{array}$ & $\begin{array}{c}2010 \\
\text { rank }\end{array}$ & $\begin{array}{c}2010 \\
\text { score }\end{array}$ \\
\hline Turkey & 120 & 0.6081 & 117 & 124 & 0.6015 & 122 & 0.5954 & 126 & 0.5876 \\
\hline
\end{tabular}

The table below shows how Turkey is ranked in the 2013 gender gap index overall and by subindex.

\begin{tabular}{|l|c|c|c|c|c|}
\hline Country & $\begin{array}{c}\text { Overall } \\
\text { rank: }\end{array}$ & $\begin{array}{c}\text { Economic } \\
\text { Participation and } \\
\text { Opportunity rank }\end{array}$ & $\begin{array}{c}\text { Educational } \\
\text { Attainment rank }\end{array}$ & $\begin{array}{c}\text { Health and } \\
\text { Survival } \\
\text { rank }\end{array}$ & $\begin{array}{c}\text { Political } \\
\text { empowerment } \\
\text { rank }\end{array}$ \\
\hline Turkey & 120 & 127 & 104 & 59 & 103 \\
\hline
\end{tabular}

Labour force participation:

\begin{tabular}{|c|c|c|c|}
\hline Country & Female (\%) & Female-to-male ratio & Rank \\
\hline Turkey & 30 & 0.40 & 123 \\
\hline
\end{tabular}

Wage equality survey:

\begin{tabular}{|c|c|c|c|}
\hline Country & Survey data & Female-to-male ratio & Rank \\
\hline Turkey & 4.46 & 0.64 & 79 \\
\hline
\end{tabular}


Estimated earned income:

\begin{tabular}{|c|c|c|c|c|c|c|}
\hline Country & Female & Male & $\begin{array}{c}\text { Female (with 40,000 } \\
\text { cut-off) }\end{array}$ & $\begin{array}{c}\text { Male (with 40,000 } \\
\text { cut-off) }\end{array}$ & $\begin{array}{c}\text { Female-to-male } \\
\text { ratio }\end{array}$ & Rank \\
\hline Turkey & 8,053 & 27,597 & 8,053 & 27,597 & 0.29 & 121 \\
\hline
\end{tabular}

\begin{tabular}{|c|l|c|c|c|c|}
\hline Country & & Female & Male & $\begin{array}{c}\text { Female-to-male } \\
\text { ratio }\end{array}$ & Rank \\
\hline Turkey & $\begin{array}{l}\text { Legislators, senior officials and } \\
\text { managers }\end{array}$ & 10 & 90 & 0.11 & 104 \\
\hline$“$ & Professional and technical workers & 36 & 64 & 0.57 & 93 \\
\hline$“$ & Literacy rate & 90 & 98 & 0.92 & 96 \\
\hline$“$ & Enrolment in tertiary education & 50 & 61 & 0.82 & 103 \\
\hline
\end{tabular}

Maternity, paternity and additional shared leaves:

\begin{tabular}{|l|l|l|l|}
\hline Turkey & $\begin{array}{l}\text { 8 weeks before birth (if multiple, 2 weeks } \\
\text { will be added) and 8 weeks after birth. If } \\
\text { it is proved with a medical report that } \\
\text { she can work until 3 weeks before the } \\
\text { birth, the remaining pre-birth leave } \\
\text { period can be shifted to the leave period } \\
\text { after the birth. }\end{array}$ & $\begin{array}{l}\text { If worker or self-employed } \\
\text { mother stays in the } \\
\text { hospital, 50\% of the daily } \\
\text { wage; if there is outpatient } \\
\text { care, 2/3 of daily wage. 100 } \\
\text { for public servants. }\end{array}$ & $\begin{array}{l}\text { 10 days after } \\
\text { servants only } \\
\text { and upon their } \\
\text { request }\end{array}$ \\
\hline
\end{tabular}

\begin{tabular}{|l|c|}
\hline Female adult unemployment rate (\% of female labour force) & 11 \\
\hline Male adult unemployment rate (\% of male labour force) & 9 \\
\hline Female part-time employment (\% of total female employment) & 24 \\
\hline Male part-time employment (\% of total male employment) & 7 \\
\hline $\begin{array}{l}\text { Share of women employed in the non-agricultural sector (\% of total non-agricultural } \\
\text { employment) }\end{array}$ & 23 \\
\hline Female workers in informal employment (\% of non-agricultural employment) & 33 \\
\hline Male workers in informal employment (\% of non-agricultural employment) & 30 \\
\hline Women who have an account in a formal financial institution (\%) & 33 \\
\hline Men who have an account in a formal financial institution (\%) & 82 \\
\hline Ability of women to rise to positions of enterprise leadership1 & 4 \\
\hline Firms with female top managers (\% of firms) & 12 \\
\hline Share of women on boards of listed companies (\%) & 8 \\
\hline Firms with female participation in ownership (\% of firms) & 41 \\
\hline
\end{tabular}

\section{Facts and Figures Regarding Woman Employment in Turkey}

As a result of their research, Demirel, et al. (1999) grouped the underlying causes of female unemployment as factual and judgmental causes. Factual reasons include the country's high unemployment rate, low wages that women receive, lack of education and skills, insufficient childcare and crèche facilities for working mothers. Judgmental reasons include values that constitute the building blocks of this system such as women's defining themselves with motherhood and men with fatherhood in the family. Woman defines her space at home whereas sees men's role and space outside the home (Kuzgun and Sevim, 2004:18).

This is an accepted fact that there are a number of prejudices in the society both in Turkey as well as globally regarding women entering the business life and rise in their career: "women leaving job due to marriage or childbirth is leading to loss of time and investment, concern of women not being able to work extra hours, male executives feel more constrained while working with women, attractive appearance of women is challenging male colleagues in the workplace, the men's role is maintaining his household and therefore have a priority in the employment process" stand out as the major problems in this context (Güldal , 2006:50)

Due to young men labor supply that are ready to work under all conditions, the demand for female labor force remains low. Employers are not willing to accept extra costs pertaining to 
women in situations as, pregnancy, maternity leave, child care etc. In addition, employers feel that long working hours and shifts may pose incompatibility with women's reproductive and motherly responsibilities and therefore avoid female employment (Toksöz, 2013:9-10).

Cinar (1994) listed sociological reasons as to why unskilled women don't work in formal jobs: (1) importance of flexible working hours for mothers with small children, (2) problems encountered related to the husband permission, (3) loss of reputation in the eyes of neighbors and relatives, (4) difficulties in promotion and raise in salary compared to male colleagues, (5) potential abuse incidents that may be encountered in the workplace (Dedeoğlu, 2000: 164).

Pinar, et. al (2010) study investigates the gender effect of a male versus a female manager in terms of business students' preferences in working for, being trained by, being motivated by, and being rewarded by one or the other. Based on 328 questionnaires, the results for the entire sample, as well as male and female subsamples, demonstrate the existence of a gender effect for all but one aspect of managing salespeople. Also, comparisons of male students to female students reveal significant differences between perceptions of the two genders in terms of the training and motivating functions. The study found that the subjects as a whole, as well as the male and female subsamples, have a preference for male managers over female managers.

\subsection{Employment and Recruitment Rates and Approach Toward Women}

The female employment rate in urban areas is $18.6 \%$ and in the public sector it is $36 \%$. Considering that public employment concentrated in cities, public sector holds an important place in the registered employment of women (TEPAV, 2014:42).

In spite of equalitarian structure in the laws, women's labor force participation rates are decreasing since 1960 . It was $34.1 \%$ in $1990,26.9 \%$ in $2002,24.8 \%$ in 2004 and $22.2 \%$ in 2007 (Mercanlıŏlu 2009: 38).

As of the end of 2010, labor force participation rate of female in Turkey was $27.6 \%$ while it was average $66.1 \%$ in the EU-27 and $60.8 \%$ in OECD countries respectively. According to this, Turkey is located on the bottom row of OECD countries in terms of women's labor force participation (Karabiylk, 2012:234).

The differences between the labor force participation rates (LFP) are decreasing as the education level of women is increasing. These minimum differences belong to the higher education graduates. Therefore, a woman to receive more training is critically important to change their LFP rates positively. There are no obvious differences in LFP rates of men in Turkey between the regions (between $64.4 \%$ and $74.7 \%$ ) whereas there are significant regional differences in female LFP rates (between 10\% and 44\%) (Yüceşahin, 2005:74).

Discrimination for women in business life shows itself in areas such as education and vocational education inequality, job placement and recruitment, wages, working conditions, workplace attitudes, promotion, layoff, access to production resources and insufficient sharing of family responsibilities. Employers (at individual trial) refuse to work with women because women may stay outside to raise children so that investments for women are lagging behind. But it is not taken into account that many women have no children. This shows that women are statistically discriminated. It is the fact that discrimination is more complex and does not occur simply from prejudice (Dolmacı and Türeli, 2012:9-10).

According to a survey that carried out in manufacturing industry (the textile, apparel and food businesses with 298 women workers) in Tokat province (Turkey), all women have pointed out gender discrimination in their workplaces. One of the women gave a quite interesting example of this discrimination: "Four months ago, 18 women and men who did ironing wanted minimum wage and insurance from the employer. Our employer has laid off nine women, gave these nine men minimum wage and also made their insurance (Özçatal, 2009:49-50).

\subsection{Sectoral or Occupational Distribution}

The number of women with higher education is less compared to males in Turkey. This fact causes women to stay away from the administrative/managerial positions. When we examine the rates of female labor force for some occupational groups in Turkey, we see 28\% are lawyers, $39 \%$ are architects, $14 \%$ are engineers, $39 \%$ are dentists, and $33 \%$ are academicians. These figures are high compared to developed countries is gratifying. However, the proportion of women situated at 
entrepreneur director and senior management positions is only 0.19\% (Kocacık ve Gökkaya, 2005:204).

In Turkey, according to a survey conducted in 2007, on the basis of occupational groups in the total workforce, only 147.000 women were legislators, senior managers and directors while 490.000 women were located in professionals occupational groups. Therefore, working women in Turkey are concentrated in occupations not requiring expertise (Mercanlığlu, 2009: 38).

In Turkey, according to 2010 data, women are employed $42.8 \%$ in the agricultural sector, $15 \%$ in industry, $0.8 \%$ in the construction sector, and $41.7 \%$ in the services sector. According to this, agricultural sector owns the highest share of employment, and women's employment is concentrated in the agricultural sector. As such, construction and industrial sector, especially the manufacturing industry still remains a sector rather limited for female labor force (Karabiylk, 2012:242).

Due to existing market structures and characteristics created by the industrial enterprises, labor markets have been divided into primary and secondary sectors. Generally the primary markets are accepted as formal sector and encompass the jobs that pay good wages and social security rights while the secondary market is comprised of informal jobs. While jobs in the primary market are seized by men, secondary market jobs are mostly performed by women (Dedeoğlu, 2000:139).

The largest increase in female employment in Turkey is seen in the services sector. The service sector and public administration are especially noteworthy in terms of female labor force employment in Turkey. The span of women in civil service consists of educational activities, health services, and telephone telegraph operators. The fields where they are mostly employed in the private sector are architect - engineering services, financial advisors, accounting clerks, cashiers, textile and food industry (Yaşar, 2007:18-19).

Patriarchal cultural values and women's roles in this gender-based division of labor define women's choice of labor, deciding which workplaces they can work at and what professions they can choose. Women's first priority is child care and domestic jobs (cooking, cleaning). These values further direct them to work in specific industrial sectors particularly the low-paid unskilled jobs considered lower in hierarchy and authority in the labor market (Özçatal, 2009:46).

Concentration of women in certain jobs and sectors has emerged as a natural application in business life according to gender separation. Gender separation configuration assumes that women are cheaper and less productive than men and fully productive during only certain phases of their lives (when they are young and unmarried), talented for only certain types of jobs (unskilled, temporary and service jobs) - verified by women's employment patterns (Dolmacı and Türeli, 2012:5).

Trained women often work in the jobs which require specialization - in the service sector - in Turkey. Untrained women are working in skill-based jobs which do not require specialization. Among them are small-scale knitwear works, knitting, buttonhole etc. Other jobs outside service sector that women do are factory worker, salesmanship, cashier, hairdressing and tailoring (Kocacık and Gökkaya, 2005:197).

There is a belief that employing women in upper management levels (control positions) in the industrial sector is a risk. Thus, women are working in only specialist positions such as human resources, corporate communications, public relations and marketing areas which are traditionally called "female functional area" and not in the career pathway of top management positions and take unauthorized responsibilities in the private sector. In addition, female employees and managers are concentrated in less earned, uniform occupations or receive lower wages than men in the same category but in areas where they can get more assignments (Göktepe, 2011: 4).

\subsection{Income Levels}

Even though women have the same human hardware as men, they work in different markets (due to their concentration in certain low status, unskilled jobs) and do not compete in the same market, women earn less. According to Human Capital Theory, literally male and female employees can be no substitute to each other. Because when women marry and have children, they tend to leave the workforce and also they are less experienced in business (Dolmacı and Türeli, 2012:9).

Due to liabilities of women for care, their intermittent or part-time participation into the labor market are the reasons for giving low-skilled jobs to women and for low paid wages. Lower 
wages to women, fewer rights and less advancement opportunities maintain the material basis of patriarchal (male dominated) system (Toksöz, 2013:6).

\section{Proposed solutions pertaining to gender equality issues in business life in Turkey}

Problem of gender equality in the business life is an area that requires the participation and supports of various stakeholders primarily the government and private sector for the determination of the problem and development of solutions. In this context, various proposals for solution to the problem have been presented (from literature and our own), extending from development of state policies to applications in the private enterprises.

- Women's position in society is the basic indicator for social development and modernization of a society and the fact that absolute termination of all kinds of sexual discrimination of women is among the anticipated targets of Atatürk for Turkish society stresses on increasing awareness and taking concrete and radical steps to overcome this issue. Experiences show that only legal regulations are not adequate. Therefore, it must be our basic aims to eliminate all factors that may prevent equality of women with men and to functionalize the state authorities as a tool ensuring positive discrimination towards women for some time. However, to achieve these, we must divert our focus from a "market"- oriented thinking, policy and economy understanding to a "human" - oriented understanding (Kaymaz, 2010:362).

- It may be suggested that in Turkey, the issue of gender equality faced by women at work place is due to mistaken beliefs and ideas arising from social values. As long as these false beliefs and ideas persist, women will continue to face similar problems. In a struggle to cope up against this situation, positively strengthen the women at work place and change the views or perceptions and attitude of other employees toward women, awareness and training programs must be organized.

- From a "constructivist" viewpoint, in social structures that currently carry and continue to produce patriarchal values, any action or thought against patriarchy is difficult to possess or practice, almost impossible. However, there are no structures that cannot be changed; for this, other than possessing individual and collective will, adequate struggle forms must be suitably developed (Tanröver, 2000:173-174). In this regard, to implement social gender equality values in private sector in Turkey that possesses patriarchal values, it can only be succeeded by individual and collective efforts.

- For overcoming the socio-cultural and economic factors causing women to stay in the background in family life, professional life and political life and for development of life long training programs, adequate funds must be allocated (Yaşar, 2007: 32-33). State budgets that are the most reflection for political decisions must be sensitized for social gender and protect gender equality. Then, this will be one of the most significant tools in decreasing the social gender inequality (Doğan, 2013:76).

-Women participating in business life must be benefited from social security services within the framework of "law of equality between men and women" protecting them against risks of illness, sudden failure to work, old age, work accidents, occupational diseases, maternity and unemployment. In addition, women who have been subjected to such risks must benefit from all social assistance services without being victims of gender discrimination (Kocacik and Gökkaya, 212). In this sense, legal measures must be exercised to prevent the working of women without formal records and registration.

- The "family" factor must not be overlooked in existence of women at employment market, in various sectors and in high managerial levels in enterprises as well as increasing the number of working women. In this context, Ministry of Family and Social Policies, Ministry of Labour and Social Security and the Ministry of Education should jointly conduct and support various projects. By this way, "empowerment of women in terms of gender equality, increasing woman education, supporting women entrepreneurs, strengthening social gender equality at work in Turkey under the leadership of institutionalized enterprises, opening woman leadership schools" can be provided.

- In order to bring up successful female executives/managers in Turkey, management departments must offer special management, leadership and entrepreneurship courses for women 
in particular. Such courses and successful woman role models fulfilling such active patriarchal positions in business life would be encouraging for new female generations to follow in their footsteps.

- Transport and security issues need to be resolved for upper level female management staff working long hours and returning home at late night hours. Fear of sexual harassment is one of the fears/factors that stop women from seeking employment and rising in their career. (Güneydoğum Derneği, 2005: 33).

- Media is one of the most effective channels of influencing the society. How "woman" is portrayed in radio, television and printed media and how working women are reflected must be reevaluated and restructured and the image of working woman must be improved. Women should not only be portrayed as an individual who simply involves in cooking, cleaning or bringing up children but also portrayed in advertisements or serials as successful working and managing women.

- Women must be liberated from discriminatory and prejudices in education. They should be trained with a mentality to do not only the traditional roles and occupations but also every kind of profession (Ylldırım, 2009:445).

- Necessary improvements are needed to enable women to participate in the primary rather than secondary job sectors. In other words, in order to increase the number of women employees not engaged in a "cheap, flexible and passive female labor for temporary and unskilled jobs" but in professional jobs in the primary sector requiring certain knowledge and skills, suitable measures facilitating women to reach the socio-economic opportunities they need in Turkey should be taken. The work life for socio-economically weak women is not able to go beyond secondary sectors. To save women from this vicious cycle, they must be supported to reach socio-economic opportunities primarily in education and training.

- Mainstreaming gender doesn't end by simply increasing the number of women within a specific institution. So, we should create and change social consciousness.

- Enabling women to engage more in management positions can be obtained by creating career paths allowing them to gain qualifications and experience they need and giving them educational opportunities without being subjected to discrimination by male colleagues. Besides, there is a need for facilitators that allow women managers to balance their time and energy between work and home (financial support for housework and child care, popularizing institutions like nursery and crèche services for woman employees and managers with small children).

- House work and child care being among the responsibilities of woman further increases the work load of a full time working woman. At this point, it is significantly important if work places could provide possibility of having nursery, crèche and kindergarten for mothers with small children. Creation of such places / facilitators aimed for proper and safe child care would support working mothers with infants and small children and thus would increase their employment rate.

- In order to resolve the elderly and child care problem that is one of the most important obstacles in women's joining the labor force; allocation of new institutions is required. While institutionalizing social care services will facilitate the participation of women in labor force, twofold improvement may be obtained by creating employment for other women in relevant public institutions that will give such services. More authority must be delegated to local governments on this issue and nursing homes, nurseries and full day working private education institutions must be established and popularized especially for part-time school students. These measures will also play important role for the dissemination of women participation in the labor force (Doğan, 2013:87-88).

- Women should be given equal representation opportunity in management, politics and in seemingly male-dominated professions and should be treated in a participatory manner. To correct this situation, positive discrimination in favor of women should be put in practice for a certain period of time (Yıldırım, 2009:445).

- There is a need for gender-sensitive drastic changes in Turkey's industrialization policies. Policies favoring durable consumer goods or such sectors as automotive, that in its current form supports male dominated employment structure, will lead to more increase in male employment. Special measures are required for women to be employed in sectors outside the traditional female work places. For example, areas under incentive program like electronic industry, manufacturing of 
medical instruments, precision and optical instruments, pharmaceutical manufacturing, biotechnology providing (medium-high technology sectors) must possess recruitment policies that would provide and prioritize the hiring of young female employees to receive vocational trainings and get recruited as qualified or skilled labor force. (Toksöz, 2013:10).

- As a country, being engaged in strategic and priority and/or new high-tech business sectors and developing these sectors will increase social income and education level - in some of these sectors there are less obstacles for women - and thus consequently would result in more involvement of women in business life with effective roles and enjoying equal gender rights.

- Women entrepreneurs should be privileged from incentives and funding programs and prioritized by angel investors.

- Addressing gender inequality in the workplace is important for companies to build strong alliances with women so that the entire team contributes to organizational success.

- In companies, data regarding gender inequality is essential as it enables employers to take effective action. Equality of opportunity is not just about up skilling women, it is about having a dedicated gender strategy that aims for long-term organizational and cultural change.

- Equal pay audits, flexible working and tackling unconscious bias all have a clear impact on women's progression, particularly at senior management levels. But, we know that change will not happen overnight. These actions, though, will equip female professionals to push for the most effective change in their organization and become gender champions and role models.

- Rising of a woman in an organization is related to practices in organizational culture focused on human, based on performance based assessment, driven by low superior-subordinate distance and gender equality (Kahraman, 2010:31). As a result, it is evident that in order to preserve the social gender equality, organization culture must be developed in accordance with above-said characteristics. In this context, the private sector enterprises in Turkey needs to be questioned as to what extent they are human focused, performance based, depict low superiorsubordinate distance, have gender equitable practices.

- Gender equality begins at the highest level of corporate governance to set an example for executives, managers and employees. Employers also need a dedicated, long-term gender strategy that aims for long-term organizational and cultural change. Therefore, "Gender equality" trainings must be given to all levels of management and staff and to all male employees, primarily to managers and directors in private sector institutions on topics such as maintaining gender equity, creating a collegial and collaborative work environment.

- Composition of board of directors, executive leadership team and staff should be analyzed. Areas, groups or occupations where there's an under-representation of women should be listed. How workforce imbalances affect the company should be determined. For example, if women are underrepresented in management positions, it deprives the organization of leadership's diverse talent.

- The availability and types of training that offer professional development for all employees, and in particular, experienced and qualified female workers who have been overlooked for promotion to higher level positions should be examined. Flexible training options should be implemented for employees whose schedules prevent them from participating in professional development activities due to scheduling conflicts. One solution is to offer remote access to online training.

- The company's fair employment practices and policies should be reviewed and updated pertaining to sexual harassment and discrimination based on sex. Organizational policies should be ensured that they are congruent with employment laws and regulations. The level of skills and training of human resources employee and labor relations staff should be determined. Research should be conducted on the needs of a diverse, gender-equal work force.

- Recruitment represents a major barrier to women's progression, and is often affected by unconscious bias. So, effective actions should be taken by organizations aiming to avoid bias in their recruitment process. One way to do is giving unconscious-bias training in recruitment. Another way is to set targets for recruitment of women at every level, particularly addressing those departments or levels that are under-represented. This of course requires thorough monitoring and measuring of the workforce. 
- Companies should carry out employee opinion surveys and exit interview questions that elicit information about working conditions, employee views about equality, training opportunities and professional development activities. And they should develop an action plan to help implement changes in response to survey results and also analyze and report the effectiveness of strategies.

- Companies should monitor and measure promotion rates, address areas of underperformance and question why women are less likely to be promoted into particular roles or departments.

- Working women are primarily responsible for coordinating family obligations, child-care arrangements and their job demands. Measures must be taken by managers to prevent unfavorable events arising as a result of work - family conflicts; adversely affecting the family due to work or affecting the work due to family issues of women employees. Such measures will increase the efficiency of employees, decrease the stress level created by these conflicts, and minimize the reflectance of problems in between family and work. Employers should be sensitive toward women employees' problems and be flexible about the issues like child care, maternity leave and thus reduce their stress level at work caused by house and family related issues (Çınar Oğuz ve İplik, 2009: 171, 179).

- To enable women employees to be as effective and functional as males, "improvement of work place environment by removing obstacles present only for females and not for males" is required (Dolmacı ve Türeli, 2012:9).

- Women participation in managerial positions can largely be materialized by taking away the burden of house work, care of child and sick or elderly and breakdown of the perception that "women cannot be managers". Relief of the victimhood of women forced to take a long break from the job due to child birth and similar reasons must be taken by government. Flexible working hours, part-time work opportunities and such facilitators should be created for women in business life (Güneydoğum Derneği, 2005: 33).

- Allowing flexible working is directly correlated with having more women in management positions. It is often rigid working patterns that prevent women from moving into senior management positions. Flexible working is an effective means of retaining more women at work.

- Family-friendly initiatives, child-care options for working parents, educational subsidies and comprehensive benefits packages that meet the needs of traditional and nontraditional family structures should be developed and implemented.

- Women in Turkish business life are still not noticed in spite of all the efforts exerted by them. Can they be considered as lost work force? How successful are women in being able to return to the same job after giving a break in services due to maternity leave or other special situations? Or even if they did get back to their job, were they able to get the same benefits and rights as they were entitled to before their break in services? Such questions need to be addressed after thorough research in terms of practices in private sector in Turkey, and control measures must be taken to eliminate such issues.

- Big institutionalized enterprises in Turkey must serve as a "role model" in extensification of good social gender equality practices in private sector; reflect these to the rest of the private sector and to society by means of social responsibility projects.

- Women executives are unable to find examples of their role models within their organization and therefore at first, they are forced to break the prejudices in the organization towards women. Women executives may face challenges like acceptance by superiors and subordinates and may also experience problems such as lack of professional friendship among peers. Presence of role models in the institutions for female employees is important for overcoming the transparent obstacles encountered by them at the work place (Güldal, 2006:67-68). For this reason, national and international role models for women managers and employees should be identified and presented by means of gender equality trainings.

- Institutions / companies with scorecards exhibiting positive discrimination toward women and employing female work force must be supported by the government and such women-friendly institutions must be rewarded with tax reductions or incentives and provided with other resources. (Güneydoğum Derneği, 2005: 16).

- Some of the problems women face in the work place due to time constraints can be solved by using such modern technologies as information technology, smart phones, computers, internet 
(for example, participation to various meetings or trainings remotely). Connections with businesses abroad can be materialized and/or continued by means of teleconference systems. Women employees may also be given the opportunity or flexibility to take their families to business trips and meetings. Information and communication technologies can provide access to employment, education, income, health services, participation, protection and safety, etc. If women are provided with such modern technologies, these digital tools would present to them an opportunity to fight longstanding inequalities in the workplace and at home.

- "Glass ceiling breakers" must be developed for women employees and potential female candidates for managerial positions. In this respect, various practices and trainings must be developed to change the perspective of men and women managers toward woman employees as well as perspective of women toward themselves.

- Women should be recovered from the tradition of motherhood-home responsibility that imprisons them at home. Instead, these responsibilities should be shared, undertaken jointly by men and women (Ylldırım, 2009:445).

- In developed countries, the women are engaged in part-time work up to $90 \%$. The fact that this percentage is very low in Turkey and not mentioned in official statistics is another issue that also needs to be evaluated (Akalp et. al., 2009:554).

- Among OECD countries, Turkey has the lowest rate of woman participation in labor force. In general, employment rate of women in the manufacturing industry in Turkey, having the highest number of urban women work force is lower than South Korea, Mexico, Malaysia and Indonesia. The fact that female employees in industrial production in Turkey are mainly unrecorded and invisible may also have a role in this result. (Akalp et. al., 2009:554).

- Legal measures must be taken to solve the issue of unrecorded female work force and to reach the actual statistical data.

- There must be training programs encouraging and supporting women's perceptions and desires to be managers and leaders. Counseling (mentoring) programs should be developed at national and international levels to convey the essence of successful women role models employed at higher managerial levels (Güneydoğum Derneği, 2005: 33).

- Women networks ("our girls' networks") have been created for the female employees in multinational companies like American Express, GE, Goldman Sachs, Johnson \& Johnson, Lehman Brothers and Time Warner to support their business and personal skills, self-esteem and relationships. Such networks can also be created in Turkish private sectors and businesses (HBR, 2006:30).

- Civil society organizations (NGOs), cooperatives and social networks should be developed for working and professional women that would increase their relationship based on mutual interest.

- There are project funds and budgets available from various sources at national and international levels (e.g. EU projects, social protection programs). Social scientists, researchers or such civil organizations, institutions should generate more projects toward this issue using all appropriate funds.

- Network with professionals of agencies and professional organizations that promote gender equality should be widened. Women should subscribe to trade journals or newsletters for innovative ways to dismantle workplace inequities.

- A database should be created (taking into account the sectoral and occupational segregation) for different female groups like employees, employers, job seekers, female professionals and female students (Güneydoğum Derneği, 2005:34).

- In today's business life and management, diverse talents, skills and capabilities are appreciated. For example, the emotional intelligence is recognized as an important ability to have by managers apart from the sixth sense. Considering the fact that these features may be more prominent in woman compared to men, it may be important to emphasize these facts especially among business enterprises so that women can take more roles in managing today's business. Individual participation as well as experiential learning through team building exercises and work groups should be encouraged within companies. 


\section{Conclusion}

Gender equality problem is not a situation encountered only in our country. It exists all over the World but manifests itself in various forms and levels in different countries and societies. The causes and effects and acknowledgement (understanding) of gender inequality vary by country as should do solutions for combating it.

This problem is defined and conceptualized by certain definitions / concepts accepted on a global basis (Gender Equality, Gender Inequality, Gender Apartheid, Gender Discrimination, Glass Ceiling, Gender Pay Gap, Male-Female Income Disparity, Inequal Strength, Equal Empowerment, Patriarchal Values, Gender-based Violation/Persecution, Sexual Violence/Assault, Mobbing, Gender Mainstreaming, Sexual and Gender Identity Rights, Reproductive Rights, Universal Declaration of Human Rights, Equal Pay for Equal Work, etc.), is measurable by means of certain indicators and parameters although there are some debates as to their interpretation and accuracy thus representation for a specific country (Global Gender Gap Index, Gender Inequality Index-GII, Gender-related Development Index-GDI, Gender Empowerment Measure-GEM, Human Development Index-HDI, etc.) and is compared between countries or societies.

One point may be noteworthy to make here is that almost all of these definitions, concepts and indexes may imply somewhat universalism. Universalism argues that each person, by merit of simply being a citizen, should be entitled to social benefits. This may mean approximating or similarizing all the citizens, societies or countries. Do all the citizens (including women), or societies (if not countries) have to bring themselves up to the same universal levels? While comparing the countries, some of these indexes may be ruling out the religious, cultural or individual preferences. For example, the whole World is facing globalization today which is causing degeneration or loss in some values, and in some societies or countries these are not appreciated fully but somewhat acknowledged due to global economic and political conjuncture. Similar situation may be prevalent in gender equality. Meaning of life for some individuals (including some women) in some societies or countries deviate depending on religion, culture and personal preferences. Do we all have to be universalistic? What do the citizens / individuals, societies or countries expect from life? What is more preferred by an individual in a society or country, happiness with less wealth or unhappiness with more wealth? Women may be facing gender inequality in a particular area but they may be happy as they are (due to beliefs etc.). In that case, shall we consider them as victims of gender inequality? Thus, the indexes may be showing negative results for gender equality, but if these are re-evaluated and implemented in terms of happiness and personal preference (for individual, family, community), the results may be different. So, we believe that these indexes should also take these preferences into consideration and be adjusted accordingly. And some societies or countries should develop targeted solutions rather than just following universal indexes as such. Because just following universal indexes and applying similar solutions may not be effective in some countries and may result in spending unnecessary financial resources. Targeting would be a better solution in a certain population.

It may not be possible to eliminate gender equality problem completely in a country. However, what is important is, to eliminate it in our country at a level of generally accepted local and universal values, we must develop new countervailing preferential strategies, policies and plans or targeted solutions specific to our country and implement these as per our ability and capacity and maintaining its sustainability.

Some of our proposals toward solution of the problems were given above. In order to do this, our recommendation is to follow the processes given below step by step or coordinately as a joint effort by all stakeholders:

- Eliminate all unrecorded employment and develop measures to record everything related to employment.

- Implement effective methods toward collecting real/actual statistical data to understand the nature, extent and causes of gender-based inequalities in Turkey in terms of their structural dimensions and diverse patterns.

- Generate a good data base and measure accurate/correct data from field.

- Analyze the data by effective assessment methods.

- Consider and identify the interconnections between different causes like sociologic, cultural, economic, political, pedagogic factors and practices that create gender inequality. 
- Identify our country's strengths, neutrals and weaknesses, threats and opportunities to eliminate this problem.

- Identify and prioritize the possible preventions and solutions in the direction of eliminating gender inequality or for propagation of gender equality and put them into practice as per our capability and capacity.

- One danger in gender mainstreaming is that large compromises can be made for small gains. So, assess and evaluate the scope and impact of the achievements of these measures and solutions applied in our country till today. Assessing the implications of any planned action (including legislation, policies or programs) in all areas and at all levels should be our strategy for making both women and men's concerns and experiences an integral dimension of the design, implementation, monitoring and evaluation of policies and programs in all political, economic and societal spheres. solution

- Revise/re-evaluate the solutions and re-define the preferential measures for sustainable

It is our belief that such a methodology will enable to alternative conceptualizations of persisting problems and the contextualization of gender equality issues in different theoretical and comparative frameworks and thus lead to developing proposals for new countervailing strategies.

\section{References:}

1. AKALP, Gizem, Ebru YENIMAN YILDIRIM ve Serpil AYTAÇ (2009), "Sanayide Kadın İşgücünün Konumu: Bursa Örneği”, Uluslararası Disiplinler arası Kadın Çalışmaları Kongresi, o5 o7 Mart 2009, Sakarya, 550-563

2. AKSAKAL, Hülya (2009), “Tekstil Sektöründeki İşgörenlerin Maruz Kaldıkları Mobbing Eylemlerinin Cinsiyet Yönünden İncelenmesi”, Uluslararası Disiplinler arası Kadın Çalışmaları Kongresi, 05 - 07 Mart 2009, Sakarya, 113-125.

3. ATAY Osman (2009), "GAP Projesinde Özel Sektörlerde Çalışan Kadın Yöneticilerin Yaşadıkları Stres”, Uluslararası Disiplinler arası Kadın Çalışmaları Kongresi, o5 - 07 Mart 2009, Sakarya, 146-159

4. BALKIR Z. Gönül (2012), "Toplumsal Cinsiyet ve Toplumsal Cinsiyet Ayrımcılığı", TÜBAKKOM 1.KADIN AVUKATLAR KURULTAYI 21-22 Nisan Ankara.

5. ÇINAR OĞUZ, Sibel ve Fatma Nur İPLİK (2009), "İş-Aile Yaşam Çatışmasının Kadın Çalışanların İş Tatmini Ve Örgütsel Bağlllıkları Üzerindeki Etkisini Belirlemeye Yönelik Turizm Sektöründe Bir Araştırma”, Uluslararası Disiplinler arası Kadın Çalışmaları Kongresi, 05 - 07 Mart 2009, Sakarya, 171-180.

6. DEDEOĞLU, Saniye (2000), “Toplumsal Cinsiyet Rolleri Açısından Türkiye'de Aile Ve Kadın Emeği”, TOPLUM VE BİLìM Dergisi, 86, GÜZ 2000, 139-170.

7. DEMİİZ, Gülhan ve Hülya YASAR (2009), "Kadın Yönetici Olmanın Anlamı: Aydın'da Bankacılık Sektörü Üzerine Bir Araştırma”, Uluslararası Disiplinler arası Kadın Çalışmaları Kongresi, o5 - 07 Mart 2009, Sakarya, 83-91.

8. DOĞAN, Alper (2013), "Türkiye'de Toplumsal Cinsiyet Eşitliğini Sağlamaya Yönelik Hizmet Veren Kamu Kurumları ve Hizmetleri Üzerine Bir Değerlendirme”, KSÜ Sosyal Bilimler Dergisi / KSU Journal of Social Sciences 10 (2)

9. DOLMACI, Nilgün ve Nesrin ŞALVARCI TÜRELİ (2012), "Varlığını Sürdüren Bir Sorun Olarak Toplumda Ve İş Yaşamında Kadına Yönelik Farklı Ve Ayrımcı Tutumlar”, Akademik Bakış Dergisi, Sayı: 33 Kasım - Aralık 2012 Uluslararası Hakemli Sosyal Bilimler E-Dergisi, ISSN:1694528X İktisat ve Girişimcilik Üniversitesi, Türk Dünyası Kırgız - Türk Sosyal Bilimler Enstitüsü, Celalabat - Kirgizistan

10. ERSOY, Ersan (2009), "Cinsiyet Kültürü İçerisinde Kadın Ve Erkek Kimliği (Malatya Örneği) -Woman and Man Identity in Gender Culture (Example of Malatya)", Firat Üniversitesi Sosyal Bilimler Dergisi Firat University Journal of Social Science , Cilt: 19, Sayı: 2, Sayfa: 209-230, Elazı $\breve{g}$

11. GÖKTEPE Esra Aydın (2011), "Formel Ve İkincil Kadın Çalışanların İstihdam Edilme Biçimlerinin İş Doyum Düzeyleri Üzerindeki Etkisi”, Akademik Baķış Dergisi, Sayı: 26 Eylül Ekim 2011 Uluslararası Hakemli Sosyal Bilimler E-Dergisi ISSN:1694-528X İktisat ve Girişimcilik Üniversitesi, Türk Dünyası Kırgız - Türk Sosyal Bilimler Enstitüsü, Celalabat - Kırgızistan 
12. GÜLDAL, Duygu (2006),"Kadın Yöneticileri Motive Ve Demotive Eden Faktörlerin Tespitine Yönelik Bir Araştırma”, T.C. Çukurova Üniversitesi Sosyal Bilimler Enstitüsü İşletme Anabilim Dalı, Yayınlanmamış Yüksek Lisans Tezi, Adana

13. GÜNEYDOĞUM DERNEĞİ, (2005) Türkiye'de Kadının İşgücüne Katılımı Raporu.

14. KAHRAMAN, Selma Dinç (2010), "Kadınların Toplumsal Cinsiyet Eşitsizliğine Yönelik Görüşlerinin Belirlenmesi”, DEUHYO ED 2010, 3 (1), 30-35

15. KARABIYIK, İlyas (2012), "Türkiye'de Çalışma Hayatında Kadın İstihdamı”, Marmara Üniversitesi İ.İ.B.F. Dergisi YIL 2012, Cilt: XXXII, SAYI I, 231-260

16. KAYMAZ, İhsan Şerif (2010) "Çağdaş Uygarlığın Mihenk Taşı: Türkiye'de Kadının Toplumsal Konumu”, Ankara Üniversitesi Türk İnkılâp Tarihi Enstitüsü Atatürk Yolu Dergisi S 46, Güz, s. 333-366

17. KOCACIK, Faruk ve Veda B. GÖKKAYA (2005), “Türkiye'de Çalışan Kadınlar Ve Sorunları", C.Ü. İktisadi ve İdari Bilimler Dergisi, Cilt 6, Sayı 1, 195-219.

18. KUZGUN, Yıldız ve Seher A.SEVIM (2004), "Kadınların Çalışmasına Karşı Tutum ve Dini Yönelim Arasındaki İlişki”, Ankara Üniversitesi Eğitim Bilimleri Fakültesi Dergisi, cilt: 37, sayı: 1, 14-27

19. MERCANLIOĞLU, Çiğdem (2009), "Cinsiyete Dayalı Eşitsizlik; Kadın Yöneticilerin İş ve Özel Hayatlarını Dengeleme Zorlukları ve Bedelleri”, Uluslararası Disiplinler arası Kadın Çalışmaları Kongresi, 05 - 07 Mart 2009, Sakarya, 35-44.

20. MIZRAHI, Rozi ve Hakan ARACI (2010), "Kadın Yöneticiler Ve Cam Tavan Sendromu Üzerine Bir Araştırma”, Organizasyon Ve Yönetim Bilimleri Dergisi, Cilt 2, Sayı 1, 2010 ISSN: 1309 -8039, s.149-156

21. ÖZÇATAL, E.Özlem (2009), "Kadınların İşgücü Piyasasına Katılımını Ve Çalışma Koşullarını Etkileyen Sosyo-Demografik Ve Kültürel Faktörler”, Uluslararası Disiplinler arası Kadın Çalışmaları Kongresi, 05 - 07 Mart 2009, Sakarya, 45-54

22. PINAR Musa, Zeliha ESER VE J. R. HARDIN, (2010), “The Gender Effect On Managing Salespeople: Business Students' Perceptions in Turkey”, Boğaziçi Journal Vol. 24, no. 1-2 1-19.

23. SOYSEKERCI, Serhat (2006), "Cinsiyet Ayrımcılı̆̆ Olarak Üstün Erillik Olgusunun Aile İşletmelerindeki Etkisi: Kuramsal Bir Bakış”, Ekonomik ve Sosyal Araştırmalar Dergisi, Güz Cilt:3, Yıl:2, Sayı:2, 3:1-26

24. TANRIÖVER, Hülya Tufan (2000), "Medya Sektöründe Kadın İşgücü”, TOPLUM VE BİLì Dergisi, 86, GÜZ 2000, 171-193

25. TEPAV (2014), "81 İl İçin Toplumsal Cinsiyet Eşitliği Karnesi”

26. YAMAK, Nebiye ve Ferhat TOPBAS (2004), Kadın Emeği ve Cinsiyete Dayalı Ücret Ayrımcılığı, İktisadi ve İdari Bilimler Dergisi, Cilt: 18, Sayı: 3-4, s.143-156

27. YAPRAK, Şenol (2009), "Kadınların Yönetim Kademelerinde Yer Almalarının Önündeki Engeller Ve Cam Tavan Olgusu”, Uluslararası Disiplinler arası Kadın Çalışmaları Kongresi, o5 - 07 Mart 2009, Sakarya, 181-192

28. YAŞAR, Okan (2012), "Türkiye'de Kadın Eğitimi, Kadınlara Ait Diğer Göstergeler Ve Çanakkale İli Örneği”, Uluslararası İnsan Bilimleri Dergisi ISSN: 1303-5134 www.insanbilimleri.com Cilt: 4 Sayı: 1 Yıl: 2007 TÜBAKKOM 1. Kadın Avukatlar Kurultayı, 21-22 Nisan2012/ Ankara

29. YILDIRIM, Neşide (2009), "Kadınlara Karsı Ön Yargı Ve Ayrımcılı", Uluslararası Disiplinler arası Kadın Çalışmaları Kongresi, 05 - o7 Mart 2009, Sakarya, 433-446

30. YÜCEŞAHİN, M. Murat (2005), "Türkiye’de Kadının İşgücüne Katılımının Coğrafyası: Kadınların Eğitiminin Rolü”, Türkiye’de Kadının İşgücüne Katılımı Raporu, 65-75

31. KALKAN, Adnan (2013), "Kadın Akademisyenlerde Kariyer Engelleri ve Cam Tavan Sendromu: Mehmet Akif Ersoy Üniversitesi Örneği, 21.Ulusal Yönetim ve Organizasyon Kongresi Bildiriler Kitabı, Mayıs 2013, 520-525

United Nations Development Programme:

32. https://data.undp.org/dataset/Table-4-Gender-Inequality-Index/pq34-nwq7

World Bank:

33. http://wbl.worldbank.org/data/exploreeconomies/turkey/2013 
The Guardian:

34. http://www.theguardian.com/news/datablog/2013/oct/25/world-gender-gap-index2013-countries-compare-iceland-uk

УДК 33

\section{Анализ и предложения решений по проблемам социального равенства в бизнес среде в Турции}

${ }^{1}$ Айше Косабасак

${ }^{2}$ Кумали Калкан

1 Университет Басари, факультет менеджмента, Турция

Доктор наук, доцент

${ }^{2}$ Университет Мевлана, Турция

Доктор медицинских наук

Аннотация. С проблемой гендерного неравенства сталкиваются во всем мире, в том числе в Турции. Наряду с этим возникает другая проблема - половая дискриминации и, следовательно, неравенство и несправедливость в предоставлении возможностей, с которыми сталкиваются женщины в обществе. Это проявляется в различных формах в деловой жизни или на рабочем месте (неравенство в сфере занятости, заработной платы, социальных пособий и образования, а также препятствия в карьерном росте, увольнении, сексуальных домогательствах/преследовании/ притеснений и др.). Авторы проводят исследование по данной проблеме и дают оценку с точки зрения гендерного равенства, с которыми сталкиваются женщины в Турции, особенно в деловой жизни. Для этой цели был проведен анализ текущей ситуации и сделаны выводы согласно историческим данным, представлены статистические сравнения против среднемировых, обсуждается в каких областях деловой жизни проблема наиболее очевидна, в связи с чем, это происходит, анализируется причина устойчивости и сдвиги к улучшению. На основании наших выводов, представлены рекомендации для возможных решений по этому вопросу.

Ключевые слова: гендерное равенство, гендерное неравенство, половая дискриминация, Турция. 